at the end of a "pre-S.1 course": mathematics, science and technical drawing. The main answer seemed to lie in the establishment by the colleges of standards of entry high and broad enough to ensure a much greater chance of success than is usual at present. These standards should apply to all National Certificate aspirants.

Summing up, Mr. Part visualized openings for some 3,500-4,000 sandwich course students a year from sixth forms, provided they had the necessary advanced-level qualifications. Those who had four appropriate passes at ordinary level of General Certificate of Education were eligible to enter directly into the second year of the National Certificate course and could thereby get their Ordinary National Certificate by, say, $18 \frac{1}{2}$ and then go either to the university by winning a Technical State Scholarship or to any of the advanced technical college courses. For those who stopped short of the General Certificate of Education or took a different route there was a whole variety of courses.

\title{
MANAGEMENT OF SMALL FIRMS
}

$\mathrm{T}$ $\mathrm{HE}$ difficulties of providing efficient management control in small engineering firms have been analysed by L. Fontaine, J. W. Walker and W. R. Spencer, of Urwick, Orr and Partners; they also make suggestions for introducing and using effective controls*.

In their paper the authors emphasize that, since nearly half of British industrial activity derives from small businesses, it is essential to our economic wellbeing that they should be well managed. If the manager is the only executive with real management ability, then he is forced to take responsibility for all sides of the business. His company is virtually a 'one-man-band' and its activities are limited to what he can personally achieve in his waking hours each day.

It is a truism that a business cannot stay still ; it must either grow larger or smaller. To meet the pressing problems of growth the manager is compelled to bring in (or promote) individuals who are capable of taking over the full responsibility for specific sides of the business. This action immediately causes new organizational problems, and the manager has to readjust his thinking and re-orientate his ideas of how he should run his business. The core of his problem is to build up a management team and to manage his business through them. His task is to set the objectives and to keep watch over the attainment (or otherwise) of these objectives by his sub-

* Management Control of Small Engineering Firms. Pp. 39. (Lon don: Institution of Mechanical Engineers, 1958.) 2s. $6 \dot{d}$. ordinates. To many managers of small businesses this can be a most difficult discipline; it is so much easier to continue to do things oneself than to learn how to ensure that others do them instead.

Although management control techniques are no substitute for dynamic leadership, they are, nevertheless, an inescapable part of the mechanisms of modern management. The principles governing these techniques have been tested and proved over and over again. The wise manager of the small business to-day will obtain a clear understanding of these principles before he applies them to specific problems; he will not import 'systems' as such, for they are unlikely to fit and will therefore fail.

The management control techniques considered by the authors are: first, the personal problems arising from the need to delegate responsibility to assistants ; secondly, the problems of how to control the design and manufacturing activities; and thirdly, the control of finance and costs and methods of ensuring profitability.

These three separate sets of management control techniques are closely interlinked and each technique is an essential piece in the whole management control pattern. It is possible to introduce isolated control techniques here and there, but the manager who is determined to set his growing business on a continuously successful course will not rest content until he has introduced adequate control over all sides of his business.

\section{THE COMMONWEALTH FUND}

$\mathrm{T}$ HE thirty-ninth annual report of the Common. wealth Fund (pp. xii +41 . New York: The Commonwealth Fund, 1957) covers the year ended June 30, 1957, in which 54 grants were voted totalling $3,808,913$ dollars, more than 90 per cent being towards the general area of health. The section dealing with medical education and community hoalth, for which 23 grants, totalling $2,009,346$ dollars, were voted, of which 11 were new, discusses the close relation and interdependence between social institutions responsible for training health personnel and those institutions and agencies through which health services are made available to the community. Following a review of the Fund's activities by the president, Mr. M. P. Aldrich, the Board decided that for the next fow years major emphasis in the health field should remain on medical education ; and its interest in community health, in medical research, in nursing and medical fellowships and awards, in related publications and in the programme of international fellowships should continue.
Cornell University received a grant for extending research on care of patients in the Comprehensive Care and Teaching Programme, which embraces both the traditional modical setting and the community and family setting. It should indicate the extent to which, and the manner in which, the application of medical skills is influenced by differing factors in the two environments. The University of Virginia School of Medicine is extending its pilot study of the diagnostic or general clinic as it affects the reorganization of tho out-patient department, and the University of Washington School of Nursing received a grant to complete a study of nursing education. Tulane University School of Medicine is studying the personality, emotional and motivational problems of medical students, and a study at the University of Chicago and at Loyola University, Chicago, is designed to develop tests for determining skill in clinical observation, in medical diagnosis and in dealing with professional situations. Grants were also made to the Faculty of Medicine at McGill 
University and to the University of British Columbia to enable them to analyse their medical school curricula; to the Georgetown University School of Medicine for revisions of the teaching programme; to the University of Kentucky for the design of a new university medical centre; to the University of Vermont College of Medicine for continued advice to small New England communities on the establishment of appropriate health and medical services. Support of the extended mental health programme of the Rip Van Winkle Clinic was continued, and the New York Academy of Medicine received grants for a study of problems in procuring and distributing whole blood in New York City and for a pilot study of the need and advisability of an intensive study of trends in the future development of medicine.

Medical research received twenty-five grants totalling 815,625 dollars. Nine were for studies of interaction between the organism and its environment, including studies of growth and development, rheumatic fever and arthritis, nine others for neurophysiological and endocrine investigations of integrative processes within the organism and the remaining seven for studies in basic biology, including the porphyrins, the structure and function of nucleic acids and nucleoproteins, the biological role of steroids, histochemical studies of the submicroscopic organization of cells and of extracellular substances, genetic studies of the mechanism of crossing over and chemical studies of virus formation. A fluid research award was made to assist the intensive research programmes in the Divisions of Chemistry and Biology at the California Institute of Technology.

The report lists nineteen fellowships in the health field and seven other awards in support of creative work, totalling 564,056 dollars, awarded in 1956-57, and also 64 international fellowships for study and travel in the United States. The list includes twenty graduates of universities in the United Kingdom and eleven officers in the Home, Oversea. Australian and Now Zealand Civil Services. In the continental programme, eight new awards were made to candidates in Austria, Italy, Switzerland, the Netherlands, Norway and Finland, and twenty-one fellowships received extensions of 3 to 9 months. Under the publications programme, which received a subsidy of 100,000 dollars, six books were issued during the year.

\section{FRAGMENTED HOLDINGS}

$\mathrm{T}$ HE problem of fragmented holdings constitutes a major obstacle to increased agricultural productivity in most of the countries of Europe. The Organization for European Economic Co-operation estimates that 28 million hectares $(70,000,000$ acres) of agricultural land are broken up into scattered fragments, often only a fraction of an acre in extent. An individual farm holding may often comprise a dozen or more of such fragments. The consolidation of these farms into more manageable and economic units is one of the most urgent needs in efforts to raise living standards among rural people. While this is widely recognized, it is difficult to obtain rapid results because of legal, social and financial difficulties. The four reports* under consideration might suggest that there is an overlapping of effort by the Organization for European Economic Co-operation and the Food and Agriculture Organization, but whereas the Working Party of the latter has a continuing function, the report from the former is the result of a special seminar, held at Wiesbaden during June 27-July 8, 1955. Moreover, there was close collaboration and in several cases the country representatives at Wiesbaden included the members of the Food and Agriculture Organization Working Party. Portugal, which has played a leading part, both with the Food and Agriculture Organization and in practical activities in the country, was not represented at Wiesbaden. In neither case did countries east of the Iron Curtain take part.

The report of the Organization for European Economic Co-operation, which begins with a summary of conclusions, prints nine technical papers

- Land Consolidation: Cheaper and More Simplified Methods (Profect No. 199.) Pp. 129. (Paris : European Productivity Agency of the Organization for European Economic Co-operation; London H.M. Stationery Offee, 1957.) 400 French francs ; 88.; 1.25 dollars Report of the Working Party of Specialists on the Consolidation of Fragmented Agricultural Holdings, Rome, Dece

Report of the First Session of the Working Party on Consolidation of Fragmented Holdings, Sub-Commission on Party on Consolidation the Furopean Commission on Agriculture, held in Lisbon, Har Use of 17-18, 1956. Report of the Second Session, held in Vienna, October 1-3, 195\%. (Rome: Food and Agriculture Organization, 1957.) which were presented at the seminar, with a brief note of the discussions, followed by summaries of reports from eleven countries and an example of consolidation from Germany.

The problems of fragmented holdings exist in the Republic of Ireland and have been energetically attacked in recent years by the Government through the Irish Land Commission, which is part of the Department of Lands. Subject to right of appeal, the Commissioners have sole power to determine from whom land is to be acquired, the price and, after consolidation, the person to whom the lands are to be allotted and at what price. Consolidation of holdings has, in fact, been part of a transfer from former landlords to tenant purchasers. The problem, as understood in Ireland and in many European countries where it is a burning political question as well as an economic one, scarcely exists in Britain. Powers were given to the British Government under the Agriculture Act of 1947 to deal with land lying idle through having been cut up and sold in plots to prospective house-builders rather than with fragmented agricultural holdings, which in the United Kingdom so often represent a deliberate attemptunjustified though it may sometimes be-to secure land of different types to make up a balanced holding. The 1940-41 Farm Survey showed the average British whole-time farm to be rather less than 100 acres, or 40 hectares-enormous by comparison with most European countries. The European need is not only to bring fragments of land together within a 'ring fence' but also to secure a minimum area as an economic holding from which the farmer can expect to wrest a modest living. Though the size of a 'viable holding' was discussed at the Lisbon meeting, no conclusions were reached.

The conclusions of the Organization for European Economic Co-operation seminar are in very general terms-the need for an agreed procedure, simplified legal conditions, need for survey, and government financial help; the Food and Agriculture Organiza. tion recognizes the need for detailed studies. 